\title{
The gender perspective in the opinions and discourse of women about caregiving
}

\author{
La perspectiva de género en las opiniones y discursos de las mujeres sobre el cuidado \\ A perspectiva de gênero nas opiniões e discursos das mulheres sobre o cuidado
}

Inmaculada Lancharro Tavero ${ }^{1}$, Eugenia Gil García ${ }^{2}$, Juana Macías Seda ${ }^{2}$, Rocío Romero Serrano ${ }^{1}$, Isabel María Calvo Cabrera $^{1}$, Almudena Arroyo Rodríguez ${ }^{1}$

How to cite this article:

Lancharro Tavero I, Gil García E, Macías Seda J, Romero Serrano R, Calvo Cabrera IM, Arroyo Rodríguez A. The gender perspective in the opinions and discourse of women about caregiving. Rev Esc Enferm USP. 2018;52:e03370. DOI: http://dx.doi.org/10.1590/S1980-220X2017009403370

${ }^{1}$ Universidad de Sevilla, Centro Universitario de Enfermería "San Juan de Dios", Seville, Spain.

${ }^{2}$ Universidad de Sevilla, Facultad de

Enfermería, Fisioterapia y Podología,

Departamento de Enfermería, Seville, Spain.

\section{ABSTRACT}

Objective: To investigate the meanings given by women caregivers to their care practices and to analyze the relationship between such practices and their work history. Method: This was a phenomenological qualitative cohort study conducted in Seville, Spain, with family caregivers. Data were collected using semi-structured interviews and submitted to content analysis, using Atlas-ti $\mathrm{GmbH}$ software version $5.0^{\circledR}$. The following categories emerged: caregiving history and work history, and the meaning of care in their lives. Results: Twenty caregivers participated in the study. Women caregivers told stories of wide-ranging care, including several individuals in their family at different moments. They performed different forms of care, encompassing physical and social dimensions. Their discourse expressed the contradiction between their caregiving role and entering and/or maintaining their place in the labor market. Conclusion: The women expressed a concept of comprehensive care that includes responsibility, availability, and companionship, as well as emotional states, which greatly impact health. They tailored their participation in the labor market according to their family's care needs. Thus, the gender perspective must be incorporated by health care providers who work with the health of caregivers.

\section{DESCRIPTORS}

Caregivers; Women; Gender Identity; Women, Working; Family Nursing. 


\section{INTRODUCTION}

In contemporary society, there has been growing interest in the topic of caregiving, and women continue being the main caregivers ${ }^{(1)}$. The feminist perspective emphasizes three aspects of care: social invisibility, the relationship between care and gender roles, and its importance to the maintenance of life $\mathrm{e}^{(2)}$.

Interest in gender issues has also grown in recent decades. Such interest has emerged outside the scope of the health sciences, which are mostly concerned with biology, i.e., aspects related to sex, not gender. In the health sector, understanding the causes of gender inequality is no simple task, because the interpretative analysis is not the most frequently used in research ${ }^{(3-4)}$.

In Spain, the Act of Promotion of Personal Autonomy and Care for Dependent Persons ${ }^{(5)}$ and more specifically, in the province of Andalusia, Decree 137/2002, that establishes the policy Support to Andalusian Families ${ }^{(6)}$, which targets caregivers, especially women, as receivers of healthcare services. However, experts claim that these forms of help are not enough and can actually contribute to increasing inequalities ${ }^{(7)}$.

The concept of work has been marked by a masculine bias that excludes an analysis of women's activities, whether domestic or mercantile ${ }^{(8)}$. The traditional male ways of participating in the labor market are only possible because caregiving roles are delegated to women. However, the growing participation of women in the labor market has not resulted in changes in distributed housework, but in the double burden on women to meet demands in both the private and public sphere, a phenomenon called the second shift $^{(9)}$; or double presence/absence ${ }^{(2)}$. The term "chore" is also used to refer to activities carried out by women, activities that sustain and care for life, which differs from the concept of "work", which is more limited and does not include the development of life ${ }^{(10)}$. Thus, some authors state their preference for the term "combine" instead of "reconcile", because it expresses the multiple facets of life instead of the expending of superhuman efforts, especially among women, to reconcile the logic of caregiving and benefits $^{(2,11)}$. Moreover, "combine" is the expression used in the 1979 UN Convention on the Elimination of All Forms of Discrimination against Women ${ }^{(12)}$.

In academic discourse, the concept of care is commonly used. It is presented, among other things, as the need to assist others, helping and accepting them, in the sense of cherishing $^{(13)}$. Caregiving refers to unpaid work performed at home, directed one's own family members ${ }^{(11)}$. It is not linear work and adjusts to the life cycle, becoming more intense when dependent individuals are involved. Thus, our concern and interest in improving the living conditions of caregivers are based on the fact that, everybody, whether men or women, will need to receive care at some point in their life cycle.

Our study is based on the gender perspective, using the standpoint theory as its framework, whose main authors are still debating concepts relative to women, point of view, and objectivity. One of the strong points of the feminist standpoint theory is that it recognizes the existence of multiple perspectives. For this reason, we propose an analysis from the standpoint of caregiving women. However, feminist theories must recognize their analytical capacity and accept their plurality and bias in order to be sufficiently inclusive and involve different women as objects of study ${ }^{(14)}$. Thus, gender is one of the most persistent forms of discrimination, a practice learned since childhood ${ }^{(9)}$.

In light of the above, the objectives of the present study were to explore the history and the meaning given by women caregivers to their care practices and to analyze the relationship between such practices and their work history.

\section{METHOD}

The aim of this phenomenological qualitative study ${ }^{(15)}$ was to analyze the experiences of women caregivers, as women are most often charged with this responsibility ${ }^{(16)}$. Qualitative methodologies shine a light on individuals' experiences and gender relationships within the singularity of specific contexts ${ }^{(17)}$. The sample was intentional, including women caregivers of dependent family members. Participants were first contacted by telephone, and all those contacted agreed to participate and had no prior relationship with the researchers. Twenty caregivers of dependent persons were chosen, residents of the province of Seville, Spain. The following variables were collected: age, occupation, marital status, and presence of children. Thus, the average sociodemographic profile of the sample was 57 years old, housewife, married, and with children. Of the twenty participants, only one caregiver had a paid job and another caregiver was single and had no children. The women signed informed consent forms and the study was approved by the Research Ethics Committee of the "San Juan de Dios" School of Nursing, to which part of the research team is affiliated. The study abided by ethical standards relative to the participants'voluntary participation and the confidentiality of their data. Data were encoded using pseudonyms, ensuring anonymity. Semi-structured interviews were carried out to gather data, a common qualitative research technique ${ }^{(18)}$, based on a pre-determined interview script. The interviews were conducted at the participants' homes, in a comfortable setting with nobody else present, and they were all completed in a single visit. Notes were taken during the interviews by the main investigator, who holds degrees in nursing and anthropology and has experience with qualitative research from the gender perspective, and who presented no conflict of interests. The aim of the interview's guiding question was to learn about the caregivers' history and relate it with the labor market experience and the impacts on their personal lives. The interviews were recorded and transcribed literally between September and December 2014, and during this period, the transcripts were also given to the participants for any comments and/or corrections. Theoretical saturation was reached on November 2014 with interview number 18; however, more interviews were conducted to ensure consistency of the results. The interviews lasted an average of 45 minutes.

Content analysis of the data included the syntax, semantic and pragmatic levels ${ }^{(18)}$. The analysis consisted of the following phases: the progressive emergence of analytical themes; 
the development of emerging categories and comparisons among them; and the transformation of emerging categories into a thesis ${ }^{(19)}$. Thus, three researchers adopted a triangulation process, in which each conducted repeated readings of the interviews based on an initial coding. The following categories were: caregiving history-work history, and the meaning of care in the caregiver's life. Repeated readings and comparisons led to subcategories, shown in the category tree diagram (Chart 1). This categorization process was conducted with Atlas-ti version $5.0^{\circledR}$ software. The validity of the analysis was based on the following dimensions: Trustworthiness, which involves the transparency of the process; Transferability, being applicable to similar situations; Dependency which involves the consistency of the presented results; and Confirmability based on data triangulation among researchers ${ }^{(20)}$.

Chart 1 - Tree diagram of categories - Seville, Spain, 2015.

\begin{tabular}{|l|l|}
\hline $\begin{array}{l}\text { 1. Caregiving } \\
\text { history and work } \\
\text { history. }\end{array}$ & $\begin{array}{l}\text { 1. a. Overlapped care. } \\
\text { 1. b. Caregiving since childhood. } \\
\text { 1. c. Care needs of caregivers. } \\
\text { 1. d. Role played in the labor market. }\end{array}$ \\
\hline & $\begin{array}{l}\text { 2. a. Caregiving actions. } \\
\text { 2. b. Concept of care. } \\
\text { 2. c. Reasons and/or motives that led } \\
\text { them to caregiving. } \\
\text { 2. Meaning of } \\
\text { care in their life. Recognition of caregiving work, } \\
\text { recognition of the person cared for, } \\
\text { self-value. }\end{array}$ \\
\hline
\end{tabular}

\section{RESULTS}

The following central categories emerged from the analysis of the women's interviews:

Category 1 - Caregiving history and work history: Includes how women take on caregiving roles for different family members, since childhood, which affects how their lives unfold.

Regarding the history of the caregivers, it is worth noting that all the twenty participants performed overlapped care, meaning that they not only cared for dependent persons, but also for other members of the family unit who were not dependent; as shown in the excerpts that follow:

Well, I care for my husband and my parents, and of course, my daughters, my grandchildren, who also need me quite a lot, I have been able to care for everyone whenever they needed it (...) (Isabel/55 years old).

I care for my mother, my mother and (...) well, also my uncle Manolillo, who lives with her, and my father too whenever he needs it. He is less dependent, but there are many things be cannot do very well, so he needs care as well (...) (Francisca/50 years old).

He's been sick for 41 years, we had been married 4 years when he got sick, and my children were little (...) he was already sick, and I struggled taking care of 4 small children, as well as my busband (Marina/65 years old).

The results also showed that the relationship of these women with care was not limited to the caregiving duties performed at the time of the study; every participant reported caregiving as being a part of their lives, since childhood. Sometimes they provided one-off care, and at other times, care required greater involvement, as shown in the following excerpts:

I began caring for my mother when I was seven years old. She had already been diagnosed with disabling rheumatoid arthritis, she had knee surgery, and I took care of her knee when she was in a wheelchair (...) (María/42 years old).

When I was a girl, my nanny, who lived here in this house with us, cared for my mother, and I was 20 years old and helped my mother with everything, I helped take care of her (Mar/69 years old).

Additionally, to capture a bigger picture of their caregiving history, the study also investigated whether the participants had ever had to receive care themselves. Three situations emerged: 1) women who declared never having needed care; 2) women who had required care at some point in their lives but had nobody to care for them; and 3) women who had required care due to various health problems and had been cared for by another woman in the family.

I was so, so, terribly ill, and the anguish of knowing you cannot be sick and you're throwing up, and you have a migraine and want to die, and you can't pick up your child and maybe she's by your side crying (...) and you have no one (Rosa/51 years old).

I had surgery, my sister took care of me, more than anyone, because the men back then weren't like the men now, like my daughter's husbands, but my sister was there for it all, radiotherapy, chemotherapy (...) (Carmen/61 years old).

Complementarily, the results regarding the labor market show that most women had to leave their paid jobs because of the irreconcilable nature of their caregiving duties. They reported the following:

I don't know, I guess I'm single and I live here, that is an essential factor, and also, they can't do it, because they work, work is another essential factor, and when this happened we all talked it over, and instead of hiring someone to work here, I left my job and stayed here, so yes, I left my job (Ana/43 years old).

They gave me a leave of absence from work and my brothers were working, so I dedicated myself to caring for her, and I dedicated myself fully, and without realizing it, I was completely involved. Perhaps I had the opportunity to work, to have a steady job, and I didn't take it because I took care of them. Yes, I guess I can say that, I lost the opportunity, but all things considered, I can say that I feel better that I took care of them (Carolina/48 years old).

When I began caring for my mother, I was working at the fruit store, because at the fruit store I could work any time, but I had to leave it, because I couldn't leave her alone, and of course, all the house chores, I had to take care of them and of my mother, so I was exhausted, exhausted, exhausted (Mari Luz/71 years old).

Category 2 - The meaning of care in their lives: Shows how care impacts the lives of caregivers and the reasons for taking on this role.

First, caregiving actions were strongly present in the discourse of the participants. They reported performing actions that ranged from the most basic to the most complex forms of care. 
So, I have to shower him every day, I have to shower and dress him in clean clothes, I put on his shoes, I make him comfortable, and all that's left is the medication. But I do this with both at the same time, my brother-in-law, I do the same thing, I give him morphine in the morning and in the evening (...) I take care of them all day long (Lidia/81 years old).

Regarding the concept of care held by the participants, they expressed beliefs that influenced the meaning of this role. The women had experience with caregiving since childhood, fostering the development of certain skills that are intertwined with feelings of tenderness, love and affection that supposedly cannot be provided by anyone else. Their answers expressed the following reasons and/or motives that led them to be caregivers: caregiving roles were attributed to their upbringing, during which the traditional female roles were ingrained. They considered caregiving their duty and did not believe that there should be social responsibility.

I was raised to believe that parents are responsible for their children, so my obligation as an only child is to take care of my parents until they are no longer here. Let's see, I believe I should take care of him, (...) because I feel obliged to (Rosario/45 years old).

I've always taken care of her, and of course, there's love, because she's my mother, and nobody else can give her that, and that's how it's going to be until the end, until the end (Joaquina/54 years old).

Furthermore, the caregivers identified the male role as incapable of care.

Of course, my mother has other children, but they are men, and of course men are different, I don't know. My brothers all work, so they can't be here like I can, always taking care of her (Angelita/68 years old).

I think that maybe the circumstances have made it so that I could be there, that my mother couldn't be alone, my upbringing too, even though the three of us were raised the same, I don't know, I've seen my brothers helping, yes, but they didn't take care of everything (Victoria/46 years old).

Even though they were skilled at caregiving, they did not recognize the value of their work. It was considered a duty that stemmed from their role as mothers, wives, daughters, etc.

I've never stopped to think whether what I do is important, I just do it, I think about giving her the best, all the best, I guess it's important for her, because she feels much better, she's not alone, she's not forgotten in some elder home, she's not being cared for by strangers, my sick person is not a piece of furniture, she's a person, she has dignity and she must keep her dignity until her last breath (Manuela/54 years old).

I don't know if it's important, really (...) it's important for my mother, yes, I think she feels cared for, assisted, I help her and dress her, and if I stop to think about it, I guess it's a good thing, but on the other hand, I don't know, I don't really think it is (Josefa/67 years old).

According to the participants, caregiving only benefitted the persons receiving care. They were unanimous in assessing themselves negatively because of the effects on their physical, psychological and social health.

Well, I've had two hernia surgeries, one on the right and the other on the left, because of strain. I'm always straining myself, turning him over to dress him in bed, I turn him over, put on one pant leg, turn him over again and put on the other pant leg, and it's strain, strain, strain (Choni/56 years old).

But there are also times when you're a bit depressed, you're alone, and you're thinking. At other times it drives me to despair, and I don't cry, because I can't (Amparo/46 years old).

$I$ had to distance myself a bit from my friends. I can't go out like I could sometimes before. I've had to leave behind some of the things I liked to do; for example, a course that I was taking and had to give up. I liked to do many things, but I can't do them anymore. Older people take up a lot of your time. They rob you of your time. But if you do it with love, and with joy, what can you do. That's how it is, but they do take up your time (Carolina/48 years old).

On some days, caregiving is a bit easier, and on other days, it's a bit harder for me, but what can I do, because taking care of him is the most important thing for me. I don't go out for anything, I don't go to a single mass, when it's the procession of the Virgin Mary (...) I stand in my doorway, it passes by here, and then I go back inside and there you have it, I can't go anywhere because I can't leave him alone, and that's my life (Lola/73 years old).

\section{DISCUSSION}

To answer the research objectives, the discussion is structured into two parts. First, it presents the literature regarding the caregiving and work history of women and that about the meaning of care as understood by women. Thus, based on the standpoint theory, the discussion recognizes the multiple perspectives of women as objects of study ${ }^{(14)}$.

The results of the present study corroborate other investigations, in which women are assigned the traditional gender role relative to caring for and ensuring the family's wellbeing, playing the roles of mothers and wives ${ }^{(21)}$. Also, caregiving encompassed extended family members and in-laws. As in other studies, the present study shows how families represent the greatest source of caregiving, marked mainly by the contribution of women and traditionally provided in the domestic setting ${ }^{(13,22-23)}$.

The social identity of caregivers is based on the interpretation of gender roles, and consequently, $76 \%$ of caregivers are related to the person receiving care ${ }^{(4)}$. However, the most relevant aspect of this social identity is not the family relationship but identifying with the female gender. Furthermore, it is also important to consider the age of the dependent persons. In the present study, two groups were observed, persons older than 65 years old and one child that was cared for by Rosa. Regarding interpersonal relationships, family ties were present in all situations.

The participants are considered members of the "sandwich generation". The findings corroborate previous studies in which women between 45 and 65 years have to care for small children, support adolescent children, while also caring for and accompany their aging parents, frequently all under the same roof ${ }^{(23)}$. In the present study, caregiving extended to the participants' grandchildren. Studies have shown that these factors are conducive to experiences of anguish and stress among this population ${ }^{(22-23)}$.

Additionally, the socialization process that occurs since childhood and that constructs gender identities impact the care provided by the women at the time of the study. The way men and women are socialized equip women to take on 
responsibilities for the dependent population ${ }^{(4)}$. The home becomes a space for socialization in which women learn traditional medicine practices and reproduce the dominant model. Families have an essential role in this regard, teaching young girls to give care, and who implement this model when building their own families ${ }^{(23)}$.

Regarding gender stereotypes, the women naturalized caregiving functions as part of the female role, and often blurred the lines between this role and that of a homemaker. They also stated that it was their personal duty and responsibility to care for family members. In general, they indicated that the traditional upbringing they received since little girls was responsible for their social identity. Based on this identity, women naturalize their caregiving roles, a process called gender socialization ${ }^{(10,21)}$.

Regarding the work profile of the participants, part of the sample had participated in the labor market before getting married, leaving their jobs on getting married and having their first child; the other part had stayed at their jobs until the dependence of a given family member required they leave it. Caregivers expressed feeling responsible for dependent family members, stating that it was impossible to reconcile paid employment with caregiving. However, some variations were observed: In Victoria's case, she kept her paid job because her work hours were compatible, and thus she represented the double presence/absence condition by performing both family and work roles ${ }^{(2)}$. The present study did not explore the relationship between the women leaving their jobs and their retirement. Thus, the researchers suggest that more studies be conducted to investigate this aspect.

The situations described in the present study reflect the traditional models of female labor force participation. With variations depending on the country and/or the patterns of female labor force participation, in general, women tend to adjust their participation in the labor market according to caregiving needs of their families, presenting non-linear participation that changes according to the life $\operatorname{cycle}^{(2)}$.

For the participants, caregiving was defined as more than just performing activities. Caregiving implied responsibility, ongoing availability, and "being with the person" they cared for and accompanying them in their health experiences ${ }^{(4)}$. Thus, caregiving was associated with emotional states and, according to the participants, are expressed in the form of care, affection, tenderness, etc.

To fully capture the meaning of care, it is presented how the participants assessed their work, the person receiving for, and themselves, cross-referencing this last category with the impacts of caregiving on their lives. The women expressed more negative perceptions of themselves than of the family members cared for. We defend the importance of naming the tasks performed by caregivers and recognizing their value, as well as not naturalizing care as a role for women, an element of social imbalance and injustice ${ }^{(9,22)}$. In contrast with other studies that have shown that caregivers do not recognize their caregiving skills ${ }^{(24)}$, in the present study, the participants did not recognize the value of the skills, i.e, they did not consider the activities performed as important, but they did consider themselves skillful. Traditionally, women's work activities have been carried out between the home and caregiving of dependent persons. Women do not expect either financial remuneration or social recognition for these activities, because women's "are" as a function of others ${ }^{(25)}$. The economic nature of the relationship of care invites a reflection about how caregiving is not necessarily an unpaid activity ${ }^{(4)}$, because some of our participants received benefits as a consequence of the Act of Promotion of Personal Autonomy and Care for Dependent Persons ${ }^{(5)}$ in force in Spain. However, the literature presents a majority of cases of women who are not paid for their caregiving work. In relation to the institutional setting of care, the participants in the present study carried out care in the family context. Sometimes this environment changes, such as in the case of hospital stays or health appointments. On these occasions, time should be be set aside to listen to and respond to the information needs of caregivers, thus promoting their health and well-being ${ }^{(26)}$.

The results of this study corroborate those of others that have analyzed the effects of caregiving on the lives of women; the results show that caregivers experience considerable emotional burdens, and are subject to anxiety and depression, experiencing lower subjective well-being ${ }^{(27-28)}$. The burden involves their physical, psychological and social lives, which results in lower quality of life. The women expressed that caregiving decreased their time availability, stopping them traveling, working, studying and/or participating in cultural activities, in addition to limiting their relationships to include only family members or neighbors.

The results of the present study have direct contributions to nursing. Other studies have shown that nursing professionals must take into account caring for caregivers ${ }^{(29)}$. Traditionally, formal and informal care are considered female roles, and therefore, from the gender perspective, the State must also participate in the care of dependent family members. Gender equality policies created in countries such as Spain include gender education of nursing students as formal caregiving agents ${ }^{(30)}$. This education helps students become aware of gender issues, allowing for reflections about what it means to be a man or a woman, and the expected behaviors, identities and roles both in the private and public domains. The goal should be to recognize the value of the care performed by women and to prevent inequality, which would improve the quality of care provided.

\section{CONCLUSION}

The history of the caregivers in the present investigation was not limited to the care provided at the time of the study. The women had taken on caregiving roles their entire lives and pointed to the impossibility of reconciling caregiving with paid work. They expressed the concept of comprehensive care that includes responsibility, availability, companionship, as well as emotional states. The results show that they did not recognize the value or importance of the work they perform, even though the persons cared for were positively assessed. They also assessed themselves negatively, in terms of physical, psychological and social health, which contributes to decreased quality of life. More studies are needed in the area to further improve the nursing care provided to caregivers. This study contributes to the field by recognizing the importance of gender education for future nursing professionals. 


\section{RESUMEN}

Objetivo: Explorar el significado que las mujeres cuidadoras dan a sus prácticas de cuidado y analizar la relación de dichas prácticas con las trayectorias laborales. Método: Estudio de corte cualitativo con diseño fenomenológico, realizado en Sevilla, España con cuidadoras familiares. La estrategia de obtención de datos ha sido la entrevista semi-estructurada. Los datos fueron analizados mediante análisis de contenido, se utilizó el software informático Atlas-ti $\mathrm{GmbH}$ versión 5.0 ${ }^{\circledR}$. Las categorías definidas son: historia cuidadora e historia laboral y significado del cuidado en sus vidas. Resultados: Participaron del estudio veinte cuidadoras. Las mujeres cuidadoras narran unas historias de cuidados extensas, cuidan a distintas personas de la unidad familiar en distintos momentos temporales. Los cuidados que desempeñan son muy diversos, contemplando la dimensión física y social. Se observa una contradicción entre el trabajo de cuidado y la incorporación y/o mantenimiento en el mercado laboral. Conclusión: Las mujeres expresan un concepto de cuidados integral que contempla la responsabilidad, la disponibilidad, el acompañamiento, así como estados afectivos, que generan un gran impacto en su salud. Las mujeres entrevistadas ajustan la participación en el mercado laboral a las necesidades de cuidados de la familia. Así, la perspectiva de género debe ser incorporada por los profesionales sanitarios que atienden los problemas de salud de las cuidadoras.

\section{DESCRIPTORES}

Cuidadores; Mujeres; Identidad de Género; Mujeres Trabajadoras; Enfermería de la Familia.

\section{RESUMO}

Objetivo: Explorar o significado que as mulheres cuidadoras dão às suas práticas de cuidado e analisar a relação dessas práticas com as trajetórias de trabalho. Método: Estudo qualitativo, com desenho fenomenológico de desígnio, realizado em Sevilha, Espanha com cuidadoras familiares. A estratégia de obtenção de dados foi a entrevista semiestruturada. Os dados foram analisados com a metodologia de análise de conteúdo, por meio do software Atlas-ti $\mathrm{GmbH}$, versão 5.0 ${ }^{\circledR}$. As categorias definidas são: história de cuidados e história laboral e o significado do cuidado em suas vidas. Resultados: Participaram do estudo 20 cuidadoras. As mulheres cuidadoras narram algumas histórias de cuidados extensas e cuidam de diferentes pessoas da unidade familiar em diferentes momentos temporais. Os cuidados que desempenham são muito diversos, contemplando a dimensão física e social. Observa-se uma contradição entre o trabalho de cuidado e a incorporação e/ou manutenção no mercado de trabalho. Conclusão: As mulheres expressam um conceito integrante de cuidados que abarca a responsabilidade, a disponibilidade, o acompanhamento, como também estados afetivos que geram um grande impacto em sua saúde. As mulheres entrevistadas ajustam a participação no mercado de trabalho com as necessidades de cuidados da família. Deste modo, a perspectiva de gênero deve ser incorporada pelos profissionais da saúde que atendem aos problemas de saúde das cuidadoras.

\section{DESCRITORES}

Cuidadores; Mulheres; Identidade de Gênero; Mulheres Trabalhadoras; Enfermagem Familiar.

\section{REFERENCES}

1. Ramón-Arbués E, Martínez-Abadía B, Martín-Gómez S. Factores determinantes de la sobrecarga del cuidador: estudio de las diferencias de género. Aten Primaria. 2017;49(5):308-313.

2. Carrasco C. Del tiempo medido a los tiempos vividos. Rev Econ Crítica. 2014;17:82-97.

3. Colomer C. El sexo de los indicadores y el género de las desigualdades. Rev Esp Salud Pública. 2007; 81(2):91-3.

4. Jesús Izquierdo M. Las dos caras de la desigualdad entre mujeres y hombres: explotación económica y libidinal. Quad Psicol. 2010;12(2):117-29.

5. España. Ley n. 39/2006, de 14 de diciembre de 2006. Ley de Promoción de la Autonomía Personal y Atención a las personas en situación de dependencia. Bol Oficial Estado [Internet]. 15 dic 2006 [citado 2016 sep. 25];(299). Disponible en: https://www.boe.es/ buscar/pdf/2006/BOE-A-2006-21990-consolidado.pdf

6. España. Decreto n. 137/2002, de 30 de abril de 2002. Decreto de Apoyo a las familias andaluzas. Bol Oficial Junta de Andalucía [Internet]. 4 may 2002. [citado 2018 abr. 6];24(52). Disponible en: http://www.juntadeandalucia.es/boja/2002/52/boletin.52.pdf

7. Del Río-Lozano M, García-Calvente MM, Marcos-Marcos J, Entrena-Durán F, Maroto-Navarro G. Gender identity in informal care: impact on health in spanish caregivers. Qual Health Res. 2013;23(11):1506-20.

8. Carrasco C. El cuidado como eje vertebrador de una nueva economía. Cuad Relaciones Laborales. 2013;31(1):39-56.

9. Esteban Gálvez A. Revisión bibliográfica: impacto de los estereotipos de género en la vida diaria de las mujeres. Un análisis desde la justicia ocupacional. TOG (A Coruña) [Internet]. 2016;13(24):1-21. Disponible en: http://www.revistatog.com/num24/pdfs/revision3.pdf

10. Molinier P, Legarreta M. Subjetividad y materialidad del cuidado: ética, trabajo y proyecto político. Papeles CEIC [Internet]. 2016 [citado 2018 abr. 6];1:1-14. Disponible en: http://www.ehu.eus/ojs/index.php/papelesCEIC/article/view/16084/14148

11. Tereso Ramírez L, Cota Elizalde BD. La doble presencia de las mujeres: conexiones entre trabajo no remunerado, construcción de afectoscuidados y trabajo remunerado. Margen Rev Trab Soc Cienc Soc [Internet]. 2017 [citado 2018 abr. 6];85:1-12. Disponible en: https://www. margen.org/suscri/margen85/tereso_85.pdf

12. Naciones Unidas. Asamblea General. Convención sobre la eliminación de todas las formas de discriminación contra la mujer [Internet]. 1979 [citado 2018 abr. 6]. Disponible en: http://www.un.org/womenwatch/daw/cedaw/text/sconvention.htm

13. Gozálvez V, Jover G. Articulación de la justicia y el cuidado en la educación moral: del universalismo sustitutivo a una ética situada de los derechos humanos. Educación XX1. 2016; 19(1):311-30.

14. Hyung Park J. "This very contaminated tool": an immanent critique of feminist standpoint theories. Fem Stud English Lit. 2015;23(3):81-115.

15. Chen HC, Teherani A. Common qualitative methodologies and research designs in health professions education. Acad Med. 2016;91(12):E5-E5. 
16. Del Rio-Lozano M, Garcia-Calvente MM, Calle-Romero J, Machon-Sobrado M, Larranaga-Padilla I. Health-related quality of life in Spanish informal caregivers: gender differences and support received. Qual Life Res. 2017;26(12):3227-38.

17. Botía-Morillas C. Cómo diseñar una investigación para el análisis de las relaciones de género. Aportaciones metodológicas. Papers Rev Sociol. 2013;98(3):443-70.

18. Taylor SJ, Bogdan R. Introducción a los métodos cualitativos de investigación. Barcelona: Paidós; 2010.

19. Vaismoradi M, Jones J, Turunen $\mathrm{H}$, Snelgrove S. Theme development in qualitative content analysis and thematic analysis. J Nurs Educ Pract. 2016;16(5):100-10.

20. Hidalgo L. Confiabilidad y validez en el contexto de la investigación y evaluación cualitativas. Sinopsis educativa. Rev Venezol Investig. 2016;5(1-2):225-43.

21. Sagastizabal M, Legarreta M. La "triple presencia-ausencia": una propuesta para el estudio del trabajo doméstico-familiar, el trabajo remunerado y la participación sociopolítica. Papeles CEIC [Internet]. 2016 [citado 2018 abr. 6];1:1-29. Disponible en: http://www.ehu. eus/ojs/index.php/papelesCEIC/article/view/15447/14126

22. Meira EC, Reis LA, Gonçalves LHT, Rodrigues VP, Philipp RR. Women's experiences in terms of the care provided to dependent elderly: gender orientation for care. Esc Anna Nery 2017;21(2):e20170046.

23. Casado-Mejía R, Ruiz-Arias E. Influence of gender and care strategy in family caregivers strain: a cross-sectional studybarrera. J Nurs Scholarsh. 2016;48(6):587-97.

24. Velásques V, López L, López H, Cataño N, Muñoz E. Efecto de un programa educativo para cuidadores de personas ancianas: una perspectiva cultural. Rev Salud Pública. 2011; 13(4): 610-619.

25. Martínez Marcosa M, De la Cuesta Benjumea C. La experiencia del cuidado de las mujeres cuidadoras con procesos crónicos de salud de familiares dependientes. Aten Primaria. 2016; 48(2):77-84.

26. Batthyány K, Genta N, Perrotta V. El aporte de las familias y las mujeres a los cuidados no remunerados en salud en Uruguay. Rev Estud Fem. 2017;25(1):187-213.

27. Muñoz González LA, Price Romero YM, Reyes López M, Ramírez M, Stefanelli MC. The experience of family caregivers of older people with depression. Rev Esc Enferm USP. 2010;44(1):32-8. DOI: http://dx.doi.org/10.1590/S0080-62342010000100005

28. Fernández MB, Soledad Herrera M. Distrés en hijas adultas que brindan apoyo a sus padres mayores. PSYKHE. 2016;25(1):1-14.

29. Bellato R, Araújo LFS, Dolina JV, Musquim CA, Corrêa GHLST. The family experience of care in chronic situation. Rev Esc Enferm USP. 2016;50(n.spe):78-85. DOI: http://dx.doi.org/10.1590/S0080-623420160000300012

30. Arroyo Rodríguez A, Chillón Martínez R, Lancharro Tavero I, Calvo Cabrera IM, Romero Serrano R, Morillo Martín MS. Formación en género en la disciplina enfermera. Intervención educativa en la asignatura "Género y salud". Género Salud Cifras. 2015;13(1):3-18. 